\title{
Performing Traditions of Tatiana's Party in P. Tchaikovsky's Opera "Eugene Onegin" (History of Stage Interpretations)
}

\author{
Svitlana Kysla (Kyiv, Ukrayina) \\ R. Glier Kyiv municipal academy of music \\ Academic singing department \\ Honored Artist of Ukraine, Associate Professor
}

\begin{abstract}
The world-famous masterpieces include Tatiana Larina's opera party is the central character of Peter Tchaikovsky's work. With a large amount of scientific literature on the characterization of the opera "Eugene Onegin" performance problems and analysis of stage versions, vocal interpretations of outstanding singers remains beyond the attention of researchers. But understanding these aspects is able to provide an intellectual foundation for the vocalist's performance. The purpose of the article is to highlight the performing traditions of Tatiana's party in P. Tchaikovsky's opera "Eugene Onegin" and to reveal the historical contribution of their sponsors in the Slavic and world opera space. For disclosure it is necessary to solve the problem: to systematize historical information about the productions of the National Opera of Ukraine of the second half of the twentieth century; to characterize the leading performing concepts of the Bolshoi Theater of Russia at the beginning of the 21 st century; to outline features of the image of Tatiana in the production of Metropolitan Opera 2007; to ascertain the traditions and innovations in the reading of the main vocal role of Tchaikovsky's opera. As a result, I state that the lyric-psychological genre of opera places on the main place the true reproduction of the characters, feelings and destiny of the heroes. This explains the exceptional importance of performing all the composer's remarks in the perspective of P. Tchaikovsky's style of music. Consideration of vocal and stage interpretation allows us to conclude on an important component for the vocalist-performer - the presence of acting talent. Tatiana's party requires not only a significant vocal and technical base, but also certain knowledge in the field of acting, which in turn provides a great opportunity for various readings to the main character of the opera $\mathrm{P}$. Tchaikovsky.
\end{abstract}

Keywords: opera, vocal interpretation, stage version, psychology, genre, style.

Постановка проблеми. У класі академічного співу вищого мистецького навчального закладу класичному вокальному репертуару відводиться значне місце. При цьому найбільшою складністю вирізняються пошуки стратегії власної виконавської інтерпретації найбільш популярних, відомих шедеврів. До їх числа належить оперна партія Тетяни Ларіної - центрального персонажу твору Петра Чайковського. При великій кількості наукової літератури щодо опери «Свгеній Онєгін» виконавська проблематика та аналіз сценічних версій, вокальних інтерпретацій видатних співаків залишається поза увагою дослідників. Але осмислення зазначених аспектів у змозі надати інтелектуальне підгрунтя виконавській діяльності вокаліста.

Аналіз останніх досліджень і публікацій. Шедевр оперної творчості П. Чайковського привертає увагу багатьох дослідників, але "вокально-виконавська 
історія" партії Тетяни досі не стала об’єктом спеціального дослідження. Окремі сторінки, що торкаються зазначеної проблеми, містить класична монографія середини минулого століття російських авторів В. Протопопова, Н. Туманіної [2]. Внеску українських співачок у виконавську традицію вистав "Свгеній Онєгін" Київської та Львівської Національних опер України присвячені стаття Н. Регеши [3] та окремі розділи досліджень Ю. Станішевського [4]. Електронні ресурси театрів світу містять інформацію щодо особливостей постановок опери в Європі та Америці. Лише декілька джерел зосереджені на аналізі психологічних особливостях жіночих персонажів як бази для виконавської інтерпретації образу Тетяни [1], тому вкрай необхідним видається доповнити і розкрити задані аспекти.

Особлива значимість опери Чайковського для світової музичної спадщини, висока репертуарність та популярність твору, а також відсутність у великому переліку спеціальних джерел саме таких досліджень які б торкалися різних аспектів сценічних та виконавських інтерпретацій образу головної героїні (Тетяни Ларіної) визначили актуальність статті.

Мета статті - зазначити виконавські традиції партії Тетяни в опері П. Чайковського "Свгеній Онєгін" та розкрити історичний внесок іх фундаторів у слов'янському та світовому оперному просторі. Цій меті підпорядковано декілька завдань: 1) систематизувати історичні відомості щодо постановок Національної опери України другої половини XX ст.; 2) надати характеристику провідним виконавським концепціям Великого театру Росії початку XXI ст; 3)окреслити особливості втілення образу Тетяни у постановці Metropolitan Opera 2007 року; 4)констатувати традиції та новації у прочитанні головної вокальної ролі опери Чайковського.

Виклад основного матеріалу. Партія Тетяни відрізняється особливим поетичним змістом та лірикою, що вимагає від виконавиці емоційної яскравості, технічної чистоти, змістовної наповненості. Тетяна - глибока цілісна натура, що здатна на сильні почуття. Оригінальність трактування головного образу опери може викликати на сцені суттєві складнощі виконавиць партії неймовірної художньої досконалості, створеної з особливою любов'ю П. Чайковським.

3 нашого виконавського досвіду витікає, що у втіленні образу Тетяни співачці слід приділити увагу створенню інтонаційного та драматургічного контрасту між 
трактуванням персонажу у I та III діях опери. Також, - в особливій увазі до кантиленного виконання партії, широкому диханню. Неймовірно важливою є увага виконавиці до психологічних підтекстів, ремарок композитора у партитурі і в тексті літературного джерела в партії Тетяни (особливо в сцені на балу в Петербурзі). При ліричній орієнтації тонусу музики, тї популярності та наспівності, особливого музичного значення у ролі, тим не менш, набувають інтонаційні складнощі вокалу: у партії Тетяни достатньо представлені незручні стрибки на широкі дисонансні інтервали, непідготовлені неакордові звуки, iї душевний смуток підтримує оркестрова лінія партитури, сповнена інтенсивним рухом гармонії (особлива прикраса та складність відхилення та модуляційні процеси).

Опера Чайковського "Свгеній Онєгін" в прочитанні українських вокалістів починає свою історію іще за життя композитора. "Відомо, що почасти історія написання славетного сценічного шедевру має українське коріння: композитор працював над оперою у Москві (травень 1877 р.), Сан-Ремо (лютий 1878 р.) та в селі Кам'янці, що на Черкащині - у маєтку своєї сестри Олександри Іллівни, дружини сина декабриста Льва Давидова. Тут, а також у селі Вірбівці, що за 12 км від Кам’янки..." [3, с. 133]. Дослідник Юрій Станішевський вказує, що київська прем’єра опери відбулася навіть раніше петербурзької - 11 жовтня 1884 рокуза участю інтепретатора та диригента Йосипа Прибика. "Головні ролі виконували відомі артисти В. Зарудна (Татьяна) та І. Тартаков (Онєгін), які не лише зрозуміли неповторний ліричний стиль автора, а й гранично щиро передали почуття своїх героїв. У 1889 р. спеціально до приїзду Петра Чайковський в Київ постановку було оновлено ..."[4, с. 68]. Тоді опера прозвучала у сценічній версії професора Петербурзької консерваторії, відомого співака Іполіта Прянишникова; у цьому тандемі диригентом був навіть сам композитор, який спеціально приїзжав у Київ у 1891 році. П. Чайковським у Києві були закладені певні виконавські традиції партії Тетяни у коментуваннях постановного процесу "від першої особи" самим Петром Іллічем, які були безжалісно порушені у 20-х рр. минулого століття. У той час - відмічає Ю. Станішевський (історик Київської опери), - панує "примітивна, спрощена інтерпретація, де про творчість і художність втілення говорити не доводиться. Загальний недолік - однотонність вираження, безбарвність фрази, вимученість жесту, відсутність захоплення... " $[4,136]$. У 50- х рр. минулого століття у Київську оперу 
повертається унікальна традиція сценічної інтерпретації та прочитання шедевру саме на засадах стильової відповідності авторському визначенню жанру опери як "ліричних сцен", яку започаткував ректор консерваторії та досвідчений диригент Олександр Климов - глибокий знавець творчості й стилю П. Чайковського. Головні жіночі партії у сезоні 1951/1952 рр. виконували Т. Пономаренко (Тетяна), Н. Гончаренко (Ольга). У наступні десятиріччя з'являються й експериментальні постановки, які надають змогу розкрити свій вокальний та артистичний дар відомим співачкам київської опери. Перш за все, це: Є. Мірошниченко, Б. Руденко, 3. Христич, Л. Чконія, Г. Туфтіна, Т. Пономаренко, Л. Лобанова, Н. Гончаренко та велична Лариса Архипівна Руденко викладачка Київської консерваторії, визначна співачка та педагог спеціального класу сольного співу авторки цієї статті. До речі, внесок двох поколінь київських вокалісток Світлани та Наталії Кислих в трактування мецо-сопранових партій опери "Свгеній Онєгін" відзначено багатьма дослідниками. Особливо плідний творчий результат на їх погляд виникає із багатьма поколіннями відомих режисерів та диригентів, серед яких: I. Молостова та С. Турчак, М. Третяк та Л. Венедиктов, диригенти В. Кожухар та А. Кульбаба. Преса відмічала як найбільш вдалий за усю історію Київської опери творчий тандем видатних майстрів української сцени. Вдамося до цитати: "Образ розсудливого, егоїстичного, а згодом закоханого Свгенія Онєгіна, створив М. Коваль. В партії Татьяни виступила артистка Т. Анісімова, Ольги - солістка театру С. Кисла, їх матері - владної, але привітної поміщиці Ларіної - О. Яценко" [4, с. 138]. Як найбільш майстерно відшліфована вистава у режисерській інтерпретації І. Молостової опера живе на провідних сценах України, а у їі виконанні беруть участь відомі співачки С. Добронравова, Ж. Закрасняна (партія поміщиці Ларіної); Н. Николаїшин, В. Ченська, Т. Ганіна, Т. Калінкіна, С. Годлевська ( партія Татьяни); Т. Пімінова, А. Швачка, Н. Кисла, I. Петрова (партія Ольги), Т. Кузьминова, М. Березовська, Н. Кисла, ( партія Няні). 3 чоловічих ролей вдалими є інтерпретації, які здійснюють М. Кірішев, В. Опенько, П. Приймак, О. Киреєв ( у ролі Євгенія Онєгіна); О. Дяченко, Ю. Аврамчук, М. Шуляк (Ленський); С. Магера, Т. Штонда, Б. Тарас, Д. Агеєв, С. Ковнір (князь Гремін). Цей виконавський склад та вокальна сольна та ансамблева манера $\epsilon$ еталонними за "...мистецькою гармонією всіх виражальних компонентів, злагодженим виконавським 
ансамблем i тонким відтворенням стилістики геніальних ліричних сцен П. Чайковського" [5, с. 636].

Цікаво, що рушійною силою видатних та стилістично відповідних сценічних інтерпретації опери Чайковського "Свгеній Онєгін" іще з минулого століття є творчий тандем російських та українських вокалістів. Так, доленосним для виходу з кризової постановочної ситуації в історії опери, виявився приїзд та участь у спектаклях корифеїв Великого театру, які співали українською мовою. Таким чином відбулося зрощення традицій слов’янського оперного мистецтва (з часів Леоніда Собінова та Пантелеймона Норцова, 20-30-х рр. ХХ ст.). Наразі у Великому театрі відбувається неоднозначний за підсумком процес розвитку цієї традиції.

Спектакль 2000 року на сцені Великого театру представляє собою реставраційну версію радянської постановки 1944 роки (декорації П. Вільямс). Режисером, як і в 1944 році, став Борис Олександрович Покровський. Виконавиця партії Тетяни Ларіної Марія Гаврилова получила досить неоднозначні відгуки преси після прем'єрного показу вистави. Ігнорування ремарок композитора, сталих традицій інтерпретацій та засобів психологізації образу робить ії героїню абсолютно байдужою до сценічної дії. Це призводить до не-відтворення певного емоційного спектра оперної партії, відсутності насичення вокалу тембральними барвами та почуттями порухів душі.

Інша постановка опери Великого театру здіснена у 2006 році силами відомого російського режисера Дмитра Чернякова радикально оновила театральну традицію та прочитання партії головної героїні. За жанром це трагікомедія, що оголює пороки російського суспільства (алкоголізм), надає особливої гостроти і сучасності багатьом сценам (наприклад, сцені дуелі). Акторське та співацьке втілення виконавиці партії Тетяни - Тетяною Моногаровою зводилося до екзальтованих емоцій божевілля, нервовості, що надавало особливих барв її чистому ліричному тембру. Задум режисера щодо втілення пограничних станів в образі, на наш погляд, виконаний Т. Моногаровою повністю. Співочий голос виконавиці доволі звучний, верхні ноти діапазону звучать об'ємно, не галасливо, а емоційне наповнення відповідає змісту тексту. Створюється цілісний образ: цікавий, правдивий і переконливий. Напевно, це один 3 рідкісних випадків, коли новаторське прочитання популярного твору оперної класики не викликає відторгнення, а по-новому висвітлює грані образу пушкінської героїні. 
Постановка 2007 року в американській Metropolitan Opera привертає увагу складом виконавців: Онєгін - Дмитро Хворостовський, Тетяна - Рене Флемінг, Ленський - Рамон Варгас, за диригентським пультом - Валерій Гергієв. Рене Флемінг співала російською і зуміла точно передати динаміку образу героїні від початку до кінця твору, що укупі з приголомшливими вокальними навичками дозволило створити одну 3 переконливих світових версій виконання партії Тетяни Ларіної.

Висновки. Таким чином, лірико-психологічний жанр опери ставить на основне місце завдання правдивого відтворення характерів, почуттів і долі героїв. Це пояснює виняткову важливість точного відтворення партії головної героїні твору Тетяни Ларіної згідно ремарок композитора та у ракурсі стильової відповідності музиці П. Чайковського. Розгляд стратегії втілення головного образу по двом напрямам вокальної та сценічної інтерпретації дозволяє зробити висновок щодо важливого компоненту для вокалістки-виконавиці - наявності акторського обдарування. Партія Тетяни вимагає наявності у виконавиці не тільки значної вокально-технічної бази, а й певних знань в області акторської майстерності, що надає у свою чергу велику можливість різноваріантних прочитань головного образу опери П.І. Чайковського.

\section{References}

1. Arshinova N.(1980). K voprosu o psikhologii zhenskogo obraza v pushkinskikh operakh P. I. Chaykovskogo [On the psychology of the female image in the Pushkin operas of P. I. Tchaikovsky] in: P. I. Tchaikovsky and Russian literature. Ed. M.E. Rittich. Izhevsk: Udmurtia. (In Russian).

2. Protopopov V. and Tumanina N. (1957). Tchaikovsky's opera. M.: Publishing House of the Academy of Sciences of the USSR, 1957. 370 p. (In Russian).

3. Regesha N. (2015). Yevheniy Onyehin Petra Chaykovskoho: 130 rokiv na kyyivs'kyy stseni [Eugene Onegin Peter Tchaikovsky: 130 years on the Kiev stage]. in: Bulletin of KNUKiM. Art Studies: A Collection of Sciences. Kiev: KNUKiM Publishing House. Vol. 32. pp. 133139. (In Ukrainian).

4. Stanishevsky Y.(2002). National Opera of Ukraine. Kyiv: Musical Ukraine. 736 p. (In Ukrainian). 